\title{
ICPC 14: what is missing?
}

\section{Ariovaldo dos Santos}

Universidade de São Paulo, Faculdade de Economia, Administração e Contabilidade, Departamento de Contabilidade e Atuária, São Paulo, SP, Brazil

\section{Paola R. Londero}

Universidade de São Paulo, Faculdade de Economia, Administração e Contabilidade, Departamento de Contabilidade e Atuária, São Paulo, SP, Brazil

Faculdade de Tecnologia do Cooperativismo, Porto Alegre, RS, Brazil

Received on 12.02.2016 - Desk acceptance on 12.15.2016 - $2^{\text {nd }}$ version approved on 06.24 .2017

\section{ABSTRACT}

The purpose of this study is to raise questions about Technical Interpretation 14 (ICPC 14) from the Accounting Standards Committee with regards to the statutory characteristics of Brazilian cooperative societies. We do not aim to provide definitive solutions by exhausting all conceptual analyses and accounting alternatives involving the reclassification of member shares, or "quotas", from net equity to liabilities, but rather to present some considerations with regards to points that are not explicit in ICPC 14. Applying the concept of adjustment to present value (APV) is the main point of this study, which was not taken into account when ICPC 14 was elaborated. Analysis of the statutes of cooperatives indicates, as a common characteristic, the obligation to always pay the redemption of members' quotas in a period of more than one year, and this leads us to conclude that for a reliable representation of the phenomenon it is necessary to recognize the APV of this reclassified liability.

Keywords: adjustment to present value, share capital, cooperatives, quotas, IFRIC 2. 


\section{CONTEXTUALIZATION}

Cooperative societies are legal entities with an aim, nature, workings, and principles that are different from for-profit organizations. Act n. 5,764/1971, article 4, defines that "cooperatives are societies of people with their own legal form and nature that are of a civil nature and not subject to bankruptcy, constituted to provide services to the associates" and differing from other organizations through unique characteristics, such as voluntary adhesion, an unlimited number of associates, variability of share capital represented by member shares, or "quotas", which are inaccessible to unknown third parties to the society. Moreover, the quorum for the workings and deliberation of the General Assembly is based on the number of associates and not on capital.

In Brazil, among the 13 operating areas, agricultural cooperatives stand out for the important role they play in the economy. According to the Brazilian Cooperatives Organization (2016) " $50 \%$ of Brazilian agricultural production passes in some way through a cooperative organization" (p. 16). According to the Ministry of Industry, Foreign Trade, and Services (2016), in 2015 alone the volume of exports carried out by cooperative societies reached 5.3 billion dollars, with the main products exported coming from agricultural operations.

Nowadays, one of the main concerns of Brazilian cooperative societies is related to the fact that members' quotas may be reclassified from net equity to liabilities.

This concern originates from November 2010, when Accounting Standards Committee Technical Interpretation 14 (ICPC 14) (Accounting Standards Committee [CPC], 2010), which addresses members' quotas in cooperative entities and similar instruments, was approved by the CPC. It bears mentioning that this ICPC is still not in force and that it is up to the Federal Accounting Council to approve and define the enforcement date.

ICPC 14 (CPC, 2010) recognizes that members' quotas can be classified as net equity, but for this the entity needs to have exclusive and unconditional power to define whether it makes the redemption payment or not, which would go against the essence and principles of cooperatives.

For Detilleux and Naett (2005), the main consequence of the proposed reclassification of the members' capital quota is the change in the financial indices of these entities, since this would make it difficult to obtain funding for all cooperative entities and weaken their financial position, causing restrictions on the growth of these societies. In certain cases, besides the restriction on growth, the entity could be led to discontinuity and negative net equity. It thus bears mentioning that in the Brazilian sample analyzed in this article, there are two cases with these characteristics.

In Spain, Arenaza (2009) analyzed the effects of this reclassification on cooperatives from Grupo Mongragón and concluded that the transfer of share capital to liabilities would produce a significant decrease of $24.5 \%$ in the net equity of these entities. Vialcanet and Salas (2014) also signaled that the main criticism attributed to this reclassification is the damage caused to cooperatives' image of solvency, consequently making their access to bank finance difficult (Arenaza, 2009; Fernández Guadaño, 2006; Marí, 2006).

On the other hand, it is argued that the enforcement of ICPC 14 (CPC, 2010) will enable accuracy of information, based on a more faithful representation in the Balance Sheet, as well as better information on the insolvency risk of cooperative entities and adherence to international accounting standards.

From our point of view, ICPC 14 (CPC, 2010) could have been more explicit, indicating the possibility of reclassifying capital to current and/or non-current liabilities and the consequent application of the concept of adjustment to present value (APV). We will return to this point further on.

\section{EXPECTED EFFECTS ON THE COOPERATIVES ANALYZED}

In light of the consequences presented by the aforementioned authors, we sought to verify the impacts of the adoption of ICPC 14 (CPC, 2010) on 58 cooperatives listed in the 400 biggest agribusiness companies in Revista
Melhores \& Maiores (Editora Abril, 2016), with a 2015 database. Table 1 presents the accounting information prior and subsequent to the simulation of ICPC 14 (CPC, 2010) adoption, if this had occurred in 2015. 
Table 1 Accounting information prior and subsequent to the simulation of ICPC 14 (CPC, 2010) adoption - in thousands of nominal reais $(n=56)$.

\begin{tabular}{ccc}
\hline & Before ICPC 14 & After ICPC 14 \\
\hline Average net equity (R\$) & 396,777 & 318,246 \\
\hline Average liabilties (R\$) & 892,207 & 970,739 \\
\hline Average debt & 0.6703 & 0.7415 \\
\hline
\end{tabular}

ICPC 14 = Technical Interpretation 14 from the Accounting Standards Committee.

Source: Elaborated by the authors.

For simplification, as the statutes have very different clauses, we only carried out full allocation of the member quotas to liabilities, without considering possible surpluses that will still be incorporated into capital; two cooperatives in the sample presented negative net equity and were excluded from the analysis. The net equity of the cooperatives analyzed would suffer a reduction of approximately R $\$ 78$ million, thus approximately $20 \%$. The debt ratio, calculated by dividing third party capital, current, plus non-current liabilities into total assets, would rise from $67 \%$ to $74 \%$, which is consistent with the literature presented up until then.
However, as Álvarez Pérez and Suárez Álvarez (2015) point out, it bears mentioning that it is not possible to make any generalization on the impacts that this procedure will cause on cooperative societies, since the consequences directly depend on the clauses contained in each statute and the respective capital structure.

Analyzing the cooperatives individually, it can be perceived that the entities with less that $50 \%$ debt tend to present a greater variation in debt ratios (see cooperative $\mathrm{K}$ in Table 2). In this table we present 11 cooperatives with a variation in debt ratio of more than $20 \%$; the names of the entities were omitted, but the values presented are real and refer to 2015 .

Table 2 Accounting information prior and subsequent to the adoption of ICPC 14 (CPC, 2010) - in thousands of nominal reais.

\begin{tabular}{|c|c|c|c|c|c|c|}
\hline \multirow[b]{2}{*}{ Cooperative } & \multicolumn{4}{|c|}{ Before ICPC 14} & \multirow[b]{2}{*}{ Debt with ICPC 14} & \multirow{2}{*}{$\begin{array}{c}\Delta \\
(\%)\end{array}$} \\
\hline & $\begin{array}{l}\text { Net equity } \\
\text { (R\$) }\end{array}$ & $\begin{array}{l}\text { Liabilities } \\
\quad(\mathbf{R} \$)\end{array}$ & $\begin{array}{c}\text { Share capital } \\
\text { (R\$) }\end{array}$ & Debt & & \\
\hline $\mathrm{A}$ & 44,519 & 166,781 & 33,817 & 0.79 & 0.95 & 20 \\
\hline$B$ & 103,216 & 142,522 & 28,535 & 0.58 & 0.70 & 20 \\
\hline $\mathrm{C}$ & $1,540,176$ & $3,182,984$ & 672,761 & 0.67 & 0.82 & 21 \\
\hline $\mathrm{D}$ & 50,466 & 66,646 & 14,297 & 0.57 & 0.69 & 21 \\
\hline$E$ & 389,816 & 359,302 & 80,065 & 0.48 & 0.59 & 22 \\
\hline $\mathrm{F}$ & 99,657 & 212,318 & 49,545 & 0.68 & 0.84 & 23 \\
\hline G & 76,251 & 192,907 & 46,746 & 0.72 & 0.89 & 24 \\
\hline $\mathrm{H}$ & 115,874 & 185,271 & 52,405 & 0.62 & 0.79 & 28 \\
\hline 1 & 867,623 & $1,109,053$ & 352,983 & 0.56 & 0.74 & 32 \\
\hline $\mathrm{J}$ & 91,178 & 92,973 & 31,430 & 0.50 & 0.68 & 34 \\
\hline $\mathrm{K}$ & $1,288,442$ & $1,085,951$ & 830,191 & 0.46 & 0.81 & 76 \\
\hline
\end{tabular}

ICPC 14 = Technical Interpretation 14 from the Accounting Standards Committee.

Source: Elaborated by the authors.

In an analysis of the different statutes of the cooperatives that operate in Brazil we did not find any that meets the full conditions of exclusively recording its quotas as net equity. This implies that all the cooperatives that we analyzed will to a greater or lesser extent have to reclassify some of their respective net equity as liabilities.

This study aims to raise questions regarding members' quotas that, for the various reasons presented in ICPC 14 (CPC 2010), will come to be recorded as financial liabilities.
Thus, the first question is whether this financial liability should or should not be adjusted to present value. If so, how should the effects of this adjustment be recorded?

Now, it may at first seem that this reasoning has no conceptual basis, as APV is a concept that is normally used to convert something that is in future value into today's money. To help in understanding this apparent impasse, we will use Technical Pronouncement CPC 12 (CPC, 2008), which concerns APV and provides valuable lessons, some reproduced in summarized form as follows: 
(i) information at present value increases the predictive value of accounting; (ii) it improves the way that present events are recognized; (iii) it increases the reliability of accounting information; (iv) accounting measurement at present value should be applied to assets and liabilities; (v) it bears mentioning that present value is not the same as fair value; (vi) it presents an example in which it shows that the present value, lower than the fair value, better represents the transaction; (vii) it predicts the change in net equity whose counter entry is a liability with financial liquidity on a different date; (viii) it draws attention to a non monetary item that by nature, like client payments in advance, will be repaid in goods and services; (ix) it establishes that assets and liabilities related to long term transactions, or short term when relevant, should be adjusted to present value with rates that reflect the best market evaluations with regards to the value of the money at the time; $(\mathrm{x})$ it determines that an adjustment is required for the liabilities, whether they are contractual or not, including for provisions.

Finally, we highlight item 8 of this pronouncement, which explicitly determines:

In terms of target to be achieved, by applying the concept of present value this procedure should be associated with the measurement of assets and liabilities taking into consideration the value of the money at the time and the uncertainties associated with them. (p. 4, own emphasis)

\section{STATUTORY CHARACTERISTICS OF COOPERATIVE SOCIETY MEMBERS' QUOTAS}

According to Act n. 5,764/1971, article 21, item III, it is up to the cooperative to determine in its statute the minimum capital, the value of the member quotas, the minimum number of quotas to be subscribed by the associate, the way these quotas are paid, as well as the conditions for withdrawing them in cases of dismissal, elimination, or exclusion of the associate. This freedom given to each cooperative society means there is great variability between the clauses that address the conditions for withdrawing members' quotas in Brazilian cooperatives.

However, some common items can be highlighted. The departure of a member refers to a request by the member themselves to exit the cooperative, and of the 35 statutes analyzed, all present the characteristic that the request cannot be denied, generally adding a reference that all debits related to the member must have been settled. Also standing out as a common clause in the statutes is that in any case of dismissal, elimination, and exclusion, the associate has the right to a refund of the nominal balance of their paid-in capital. In some cases the cooperative also commits to refunding the values related to surpluses incorporated into the paid-in capital and other credits that the member may present. For these cases, even though it is not explicitly foreseen in ICPC 14 (CPC, 2010), it seems that the reclassification to liabilities should also consider the aforementioned surpluses.

Twenty-two statutes out of the 35 analyzed also present a clause for full or partial refunding of paid-in capital to members that present a certain age and length of stay in the cooperative. In these cases the capital is refunded, but the member retains member rights. It is noted that there is an intense legal discussion regarding member rights for the case of full capital refunds, since according to some specialists it damages principles of cooperatives and legal aspects.

The conditions for refund payments for dismissal, elimination, exclusion, or age and time of stay in the cooperative are of the most diverse possible, often with timeframes greater than two, five, or ten years, but they commonly have as a minimum timeframe the assembly that approves the financial statements related to the end of the accounting period in which the member goes on to have the right to a refund for the value.

Among the 35 Brazilian agricultural cooperative statutes that we analyzed, it was possible to perceive that this financial liability does not have short term characteristics, since as a general rule these statutes present restrictive clauses for redemption payments. Among these restrictions, we present some examples taken from the statutes analyzed: (i) refunds for dismissal, elimination, or exclusion will be made in five annual installments, the first being immediately after approval of the accounts for the financial period in which the separation occurred; (ii) refunds of share capital will be made in the same timeframe in which it was paid in, starting from the financial period following the separation; (iii) payments can occur in cash installments of $2 \%$ for each year completed as a member of the cooperative, and the rest in installments up to five years; and (iv) refunds will be in annual installments, in equal numbers to the years they were a member, limited to the minimum value of 35 times the value of Unidade Padrão Fiscal do Rio Grande do Sul (Fiscal Standard Unit of Rio Grande do Sul) (UPF-RS), equivalent to R $\$ 600$ for the reference year of 2016.

Very importantly, refunds of the values of members' quotas in the case of dismissal, elimination, or exclusion, as well as in the case of cooperatives that present refund 
clauses for quota values based on the age of the member and time in the cooperative, are based on the nominal values of the paid-in quotas and possible surpluses already incorporated into share capital; that is, they do not grant the right to net assets.

As previously highlighted, this essay does not intend to offer an objective solution or a set of criteria capable of clearly defining liabilities and net equity, but rather to initiate a discussion on the way of measuring cooperative members' quotas, given the classification as financial liabilities indicated in ICPC 14 (CPC, 2010) and consequent accounting.

\section{LIABILITIES AND APV}

The concepts of liabilities and net equity can be explored through the different approaches that have been improved with the development of companies and accounting itself. For example, with the entity theory approach, it is assumed that an accounting entity exists distinctly from owners and creditors and that segregation of the entity's obligations is not necessary (Canning, 1929). From the viewpoint presented by Vatter (1947), known as fund theory, segregation is guided by specific purpose activities connected to creditors or owners. With ownership theory, the entity must be analyzed from the owners' viewpoint, property instruments are classified as equity, and all others are liabilities or assets. For López-Espinosa, Maddocks, and Polo-Garrido (2012), the adoption of different approaches means that there is a need to alter the concept of liabilities and net equity.

According to CPC 00 (2011a), which refers to the Conceptual framework for elaborating and publishing accounting-financial reports, a liability can be defined as an "obligation present in the entity, derived from past events, whose liquidation is expected to result in the departure of resources from the entity capable of generating economic benefits" (item 4.4). This liability can be classified as current or non-current, according to CPC 26 - Presentation of accounting statements (2011b).

ICPC 14 (CPC, 2010) does not provide guidance on the classification of the quotas that will be allocated to liabilities as current or non-current. However, given the refund payment periods for the quotas foreseen in the statutes of the cooperatives analyzed, there is the possibility of refunds in timeframes greater than the operating cycle of the cooperative or 12 months after the date of the balance sheet, consequently indicating classification in non-current liabilities. Given the quota refund periods foreseen in the statutes, these quotas cannot be seen as being of an indefinite timeframe. However, if the statute omits the question, the quotas should be classified as being of an indefinite timeframe.

Thus, according to the guidelines of CPC 12 (CPC, 2008), which refers to APV, a transaction that gives rise to a liability whose counter entry is an asset or a liability with financial liquidation (receipt or payment) on a different date from the date this element is recognized may be subject to APV. Added to this is what is included in item III, of article 184 of Brazilian Corporate Law, altered by Act n. 11,941/08, which determines that: "the obligations, charges, and risks classified in non-current liabilities will be adjusted to their present value, with the rest being adjusted when there is a relevant effect".

Santos (2012) indicates that "present value represents the estimate of future cash flows measured in current currency at a particular moment" (p. 116). Szüster (2015) mentions that accounting measured at fair value applied using the full monetary correction method is an ideal to be sought, with transactions at fair value being a necessary path towards this improvement.

Hendriksen and Van Breda (1999) argue that the idea of the fair value calculation for future cash flows has merit in the economic concept of profit, and even presenting some practical challenges for accounting purposes, a suitable focus enables more useful information for the user of the information.

CPC (2011a), via its conceptual framework, declares that for accounting-financial information to be considered useful, it needs to be linked to a relevant phenomenon, as well as faithfully representing the phenomenon that it proposes to portray. Thus, APV of cooperative members' quotas enables a more faithful representation of the phenomenon, bringing it closer to the economic reality. It bears mentioning that besides what is set out in item QC15 of CPC 00 (CPC 2011a), faithful representation does not mean exactness in all aspects; accounting is based on estimates and is surrounded in uncertainty; however, faithful representation represents the best estimate at the time of reporting.

According to Martins, Gelbcke, Santos, and Iudícibus (2013), to determine the APV, "basically three pieces of information are required: (i) future cash flow; (ii) the date on which this flow will occur; and (iii) the discount rate that should be used" (p. 114). According to these authors, the discount rate that should be used is the effective rate on the date of transaction, and in the case of implicit 
rates, the recommendation is to use the market interest rate that is practiced in transactions of a similar nature, with similar timeframes and risks.

Item 10 of ICPC 14 (CPC, 2010) determines that cooperatives should measure these liabilities by their fair value, which should be "a value not lower than the maximum value payable, in accordance with the redemption provisions in their statutes or the applicable legislation, discounting from the first date on which the value to be paid could be demanded". Martins, Gelbcke, Santos, and Iudícibus (2013) highlight the differences between fair value and APV; while APV considers the value of the money at the time, fair value aims to show the market value of a particular asset or liability.

Szüster, Szüster, and Szüster (2005) note that the items seen as liabilities derived from transactions with pre-set values should be discounted, considering the purchasing power forecast for the effective payment date. CPC 12 (CPC, 2008) foresees that the APV, when applicable, should be calculated at the time of the initial transaction; that is, in the case of cooperative societies, when the members' quotas are transferred to liabilities. Thus, the measurement of present value should consider the cash flows for the corresponding transaction (value, date, and all the contractual terms and conditions), as well as the discount rate applicable to the transaction, on the date of its occurrence.

As can be seen from what has been laid out up until here, the financial liability that cooperatives will go on to recognize, in its essence, because it is long term, should have some type of adjustment, according to the guidelines contained in CPC 12 (CPC, 2008). Of course we are not saying here that a member's quota can be, for example, compared to the suppliers account related to a long term acquisition, since in these cases the purchase is in future purchasing power currency. As for quotas deposited by members, these are presented in nominal values from the past; moreover, they will be redeemed for exactly this nominal value only in the future. This also leads us to reflect on whether the discount rate practiced on the transfer date can be maintained forever; after all the minimum that should be effectively recognized is the loss in the purchasing power of the currency at the time. In short, this is a point to be considered by the CPC.

In his post-doctoral thesis, Martins (1980) indicates that accepting that inflation causes losses to monetary assets is much easier than accepting that a liability produces earnings, especially when this liability is associated with financial charges. In this context, Ross, Westerfield, and Jaffe (2002) argue that inflation is an important element that should be treated coherently by accounting, given that it can represent both a loss and a gain in purchasing power.

Considering that the quota paid in by a member is kept at nominal value and is not updated in any way from the moment it is paid in until its respective redemption, the cooperative will make a gain related to the value of the money at the time, while the member will incur a loss in their purchasing power.

\section{ACCOUNTING ALTERNATIVES NEED TO BE STUDIED}

It is not our intention in this essay to examine all of the accounting alternatives for these transactions that can be considered as novelties. As previously highlighted, the value of future cash flow will be the nominal value of the member's quota, given that it will be the redemption value when this is required or demanded. The date on which this cash flow will occur will depend on the provisions for payment contained in the statutes, and as has been previously highlighted and shown, this can vary considerably, normally extending into a period of more than one year.

Our assumptions for suggesting forms of accounting will consider particular aspects of the statutes of cooperatives as being similar. Among these aspects we can mention the following: (i) after the adoption of ICPC 14 (CPC, 2010), members' quotas that are not liable to the cooperative's unconditional right to refuse redemption will be transferred into the entity's liabilities; (ii) the quotas related to the redemptions that were already requested and the payments will occur within a year and will be considered as current liabilities, and the rest will be classified as non-current; (iii) the minimum capital stipulated in the statute will be maintained in net equity; (iv) the APV should be recognized at the time of transfer from quota capital to liabilities, as defined by ICPC 14 (CPC, 2010) and CPC 12 (CPC, 2008); (v) the initial reclassification will be to non-current liabilities; (vi) at the time the redemption is requested or demanded, the reclassification to current will be carried out according to the guidelines of CPC 26 (CPC 2011b); and (vii) we will not address possible taxation issues that might arise depending on the option chosen for recording as revenue and expense.

It bears mentioning that ICPC 14 (CPC, 2010) does 
not make any reference to the minimum capital stipulated in the statute of each cooperative and its classification; however, it is understood that in the absence of this minimum capital, as well as the permanence of 20 people in the society, they are essential for the continuity of the cooperative.

Given these assumptions, the first record to be made is the transfer of the value of the share capital to noncurrent assets. As it seems that, legally, the share capital account cannot be "debited", since the statutes of Act n. 13,097/2015 define share capital in net equity, the suggestion is for a rectifying capital account to be created. The counter entry for this, or rather, the credit in noncurrent liabilities, could be recognized in an account that represents this obligation for the members, for example "capital to refund". Subsequently, as a long term debt is concerned, an entry is required that reflects the present value of this debt. Thus, an account could be recorded that recognizes the reduction in long term debt, "APV of capital to refund", against one that will be classified in net equity and that could be "other comprehensive income", "earnings for future recomposition of capital", "monetary gain on capital paid-in by members", or "adjustment to equity evaluation", among others.

As time passes, the earnings on the debt recorded in nominal values are realized and should therefore be recognized. We understand that some alternatives could be used for recording this appropriately. As the subject has not yet been properly evaluated and discussed, we envision that the possibility for recording will depend on the alternative chosen.

These possibilities could be raised by more in-depth studies than the one presented in this essay. It is hoped that among the various possibilities, academics and researchers will provide a contribution that can help in offering solutions that contribute to obtaining the best accounting information possible.

\section{FINAL REMARKS}

In light of the above, one question remains: without recognizing the APV of members' quotas transferred to liabilities, how will we be able to argue that the accounting statements of cooperatives are producing information that faithfully represents the evaluation of their equity? If the aim of ICPC 14 (CPC, 2010) is to enable a more faithful representation of the information contained in the Balance Sheet of these entities, there are important questions that have not been contemplated by the aforementioned instruction.

Considering the statutes of Brazilian cooperatives, it is possible to perceive that this financial liability does not have short term characteristics, since as a general rule these statutes present clauses that impede the payment of redemptions in less than a year. This represents a clear indication of the need for adjustment to present value, in accordance with the determination of CPC 12 (CPC, 2008), for quotas that are transferred to liabilities.

It is clear after carrying out a preliminary analysis that the adoption of ICPC 14 (CPC, 2010) will result in an increase in the debt ratios of cooperatives. Some more so, others less so, but the debt ratios of cooperatives will be affected. As seen, in exceptional cases the reclassification of the portion of capital to liabilities can leave net equity with a negative value. These consequences depend directly on the clauses contained in each statute and the respective capital structure of the cooperative.

Finally, we conclude that ICPC 14 (CPC, 2010), which presents quite a solid set of concepts and practical cases, needs complementary studies in order for the accounting statements of cooperative societies to be able to faithfully represent the equity position of these entities. 


\section{REFERENCES}

Álvarez Pérez, B., \& Suárez Álvarez, E. (2015). Calificación de instrumentos financieros en las sociedades cooperativas a raíz de la NIC 32. La solución española. Revista Innovar Journal Revista de Ciencias Administrativas y Sociales 25(9), 9-20.

Arenaza, I. (2009). Accounting in a cooperative company. International Journal of Technology Management and Sustainable Development, 8(1), 57-67.

Canning, J. B. (1929). Economics of accountancy: a critical analysis of accounting theory. New. York: The Ronald Press Company.

Comitê de Pronunciamentos Contábeis. (2010). Interpretação Técnica ICPC 14 - Cotas de cooperados em entidades cooperativas e instrumentos similares. Retrieved from http:// www.cpc.org.br/CPC/Documentos-Emitidos/Interpretacoes/ Interpretacao $? \mathrm{Id}=23$.

Comitê de Pronunciamentos Contábeis. (2011a). CPC 00 (R1) - Estrutura conceitual para elaboração e divulgação de relatório contábil-financeiro. Retrieved from http://www. cpc.org.br/CPC/Documentos-Emitidos/Pronunciamentos/ Pronunciamento $? \mathrm{Id}=80$.

Comitê de Pronunciamentos Contábeis. (2011b). CPC 26 (R1) - Apresentação das demonstrações contábeis. Retrieved from http://www.cpc.org.br/CPC/Documentos-Emitidos/ Pronunciamentos/Pronunciamento? $\mathrm{Id}=57$.

Comitê de Pronunciamentos Contábeis. (2008). CPC 12 - Ajuste a valor presente. Retrieved from http://static.cpc.mediagroup. com.br/Documentos/219_CPC_12.pdf.

Detilleux, J., \& Naett, C. (2005). Cooperatives and International Accounting Standards: the case of IAS 32. Revue internationale de léconomie sociale, 295, 1-13.

Editora Abril (2016). 400 Maiores Agronegócio. Revista Exame: Melhores \& Maiores, edição especial 2016, 386-401, São Paulo, SP: Autor.

Fernández Guadaño, J. (2006). Diferentes consideraciones en torno al capital social de las sociedades cooperativas. Revista de Estudios Cooperativos (REVESCO), 88, 42-61.

Hendriksen, E. S., \& Van Breda, M. F. (1999). Teoria da contabilidade (Antonio Z. Sanvicente, trad., 5a ed. americana) (10a reimp.). São Paulo, SP: Atlas.

Lei $\mathrm{n}^{\circ}$ 13.097, de 19 de janeiro de 2015. (2015, 19 de janeiro). Capítulo XV - do capital social das cooperativas. Diário Oficial da União, Poder Legislativo, Brasília, DF.

Lei $\mathrm{n}^{\circ}$ 5.764, de 16 de dezembro de 1971. (1971, 16 de dezembro). Define a política nacional do cooperativismo, institui o regime jurídico das sociedades cooperativas e dá outras providências. Diário Oficial da União, Poder Legislativo, Brasília, DF.

López-Espinosa, G., Maddocks, J., \& Polo-Garrido, F. (2012). Co-operatives and the equity-liabilities puzzle: concerns for accounting standard-setters. Accounting Horizons, 26(4), 767787.

Marí, S. (2006). Efectos de la aplicación de la CINIIF 2 en las cooperativas. Un estudio empírico en dos cooperativas citrícolas de la Comunidad Valenciana a través del análisis económico-financiero. Revista de Estudios Cooperativos, 89(89), 84-107.

Martins, E. (1980). Análise da correção monetária das demonstrações financeiras (1a ed.). São Paulo, SP: Atlas.

Martins, E., Gelbcke, E. R., Santos, A., \& Iudícibus, S. (2013). Manual de contabilidade societária: aplicável a todas as sociedades (2a ed.). São Paulo, SP: Atlas.

Ministério da Indústria, Comércio Exterior e Serviços. (2016). Balança comercial brasileira: cooperativas. Retrieved from http://www.mdic.gov.br/comercio-exterior/estatisticas-decomercio-exterior/balanca-comercial-brasileira-cooperativas.

Organização Brasileira das Cooperativas. (2016). Relatório de gestão OCB 2015. Retrieved from http://www. brasilcooperativo.coop.br/GERENCIADOR/ba/arquivos/ relatorio_de_gesta_ocb_2015_impresso.pdf.

Ross, S. A., Westerfield, R. W., Jaffe, E. J. (2002). Administração financeira: corporate finance (Antonio Z. Sanvicente, trad., 2a ed. americana) (11a reimp.). São Paulo, SP: Atlas.

Santos, A. (2012). Ajuste a valor presente. In: Mosquera, R. Q., \& Broedel, A. L. (Orgs.), Controvérsias jurídico-contábeis (pp. 116-128). São Paulo, SP:Dialética.

Szuster, N. (2015). Temos do que nos orgulhar na Contabilidade brasileira. Revista Contabilidade \& Finanças, São Paulo, editorial, 26(68), 121-125.

Szüster, N., Szüster, F. R., \& Szüster, F. R. (2005). Contabilidade: atuais desafios e alternativa para seu melhor desempenho. Revista Contabilidade \& Finanças, 16(38), 20-30.

Vatter, W. J. (1947). The fund theory of accounting and its implications for financial reports. Chicago, IL: University of Chicago Press.

Vialcanet, R. B., \& Salas, O. A. (2014). Efectos económicos de la primera aplicación de las normas contables adaptadas a la NIC 32 en las cooperativas. Revista de Contabilidad - Spanish Accounting Review, 17(2), 201-211.

\section{Correspondence address:}

\section{Ariovaldo dos Santos}

Universidade de São Paulo, Faculdade de Economia, Administração e Contabilidade,

Departamento de Contabilidade e Atuária

Avenida Professor Luciano Gualberto, 908 - CEP: 05508-010

Cidade Universitária - São Paulo - SP - Brasil

Email: arisanto@usp.br 